\title{
Pendidikan Agama Islam Berwawasan Interdisipliner sebagai Corak dan Solusi Pendidikan Agama Islam Era 4.0
}

\author{
Rahmat $^{1}$ \\ ${ }^{1}$ Institut Pesantren KH.Abdul Chalim Mojokerto \\ ${ }^{1}$ rahmatpaikhac@gmail.com
}

\begin{abstract}
Islamic Education (PAI) in Higher Education is a subject that has received a lot of criticism from various circles because PAI which is also referred to as a scientific discipline is only like discussing halal and haram laws and the prospect of discussion is only memorizing doctrinal propositions. On the other hand, PAI is then required to be friendly with social behavior and sensitive to the development of information and technology in this era 4.0. With descriptive qualitative research methods (library research) researchers try to examine and look deeper into Interdisciplinary Insightful Islamic Education for students as a feature and solution to the Era 4.0 Education. The results of this study obtained that the interdisciplinary approach that the researchers offer is to use the disciplines of Arabic, English, Information, and Technology (IT), Accounting and Ahlus Sunnah Wal Jama'ah (ASWAJA). With these 5 scientific disciplines, the Interdisciplinary PAI will be able to become the style and solution of the Islamic Education Era 4.0.
\end{abstract}

Key Word: Interdisciplinary Islamic Education, Education era 4.0.

\begin{abstract}
Abstrak
Pendidikan Agama Islam (PAI) di Perguruan Tinggi merupakan sebuah mata kuliah mendapat banyak kritikan dari berbagai kalangan dikarenakan PAI yang juga disebut sebagai disiplin ilmu tidak ubahnya hanya membahas hukum halal dan haram serta prospek bahasannya hanya hapalan dalil yang bersifat doktrin. Di sisi lain, PAI kemudian dituntut untuk dapat ramah dengan prilaku sosial dan peka akan perkembangan informasi dan teknologi di era 4.0 ini. Dengan metode penelitian kualitatif deskriptif (library research) peneliti mencoba mengkaji dan melihat lebih dalam terkait Pendidikan Agama Islam Berwawasan Interdisipliner bagi mahasiswa sebagai corak dan solusi Pendidikan Era 4.0. Hasil dari penelitian ini diperoleh bahwasanya pendekatan interdisipliner yang peneliti tawarkan adalah menggunakan disiplin ilmu Bahasa Arab, Bahasa Inggris, Informasi dan Teknologi (IT), Akuntansi dan Ahlus Sunnah Wal Jama'ah (ASWAJA). Dengan ke-5 disiplin keilmuan tersebut maka PAI Berwawasan Interdisipliner akan dapat menjadi corak dan solusi Pendidikan Agama Islam Era 4.0.
\end{abstract}

Kata Kunci: Pendidikan Agama Islam Interdisipliner, Pendidikan era 4.0.

\section{Pendahuluan}

Belakangan ini dunia pendidikan menghadapi berbagai tantangan yang sangat kompleks. Tantangan itu berasal dari dalam maupun dari luar akibat pengaruh perubahan 
zaman yang sedang menguasai wacana dan implementasi pendidikan di seantero dunia ini. Tantangan-tantangan ini merupakan stimulus yang menghendaki adanya respons dari dunia pendidikan termasuk Pendidikan Agama Islam (PAI) harus mengambil sikap tertentu, sebagai refleksi dari karakteristiknya sendiri. ${ }^{1}$

Pergerakkan arus globalisasi yang kian hari semakin deras tentu tidak dapat terelakkan pengaruhnya bagi Negara Indonesia. Salah satu dari pengaruh globalisasi adalah dengan adanya perkembangan teknologi yang semakin canggih yang kehadirannya sebagai salah satu penanda era revolusi industri 4.0, dimana pada era ini semua aktivitas ditekankan pada pola Pendidikan serba digital economy, kemudian artificial intelligence, big data, dan robotic, atau dikenal pada zaman fenomena disruptive innovation. Disinilah pemerhati pendidikan, pelaku pendidikan itu sendiri dan sebuah lembaga pendidikan harus mengambil peran dalam meyiapkan serta mengupayakan sumberdaya manusia yang siap secara mental maupun kemampuan guna menghadapi era rovulusi industry 4,0 tersebut.

Layaknya sebagaimana menghadapi era MEA (Masyarakat Ekonomi Asia), pada era 4.0 ini pendidikan Islam akan turut serta untuk menyesuaikan diri dalam dunia pendidikannya. Dengan demikian Pendidikan Agama Islam dalam menghadapi era 4.0 ini dapat berperan dalam pengambilan kebijakan ataupun penetapan implementasi pembelajarannya dengan menggunakan kurikulum terutama materi ajar yang memang ketika diajarkan dapat mengarahkan ${ }^{2}$ dan menghasilkan peserta didik yang siap bersaing di era 4.0.

Sehingga pemilihan Pendidikan Agama Islam Berwawasan Interdisipliner merupakan langkah yang tepat, sebab problem Pendidikan Agama Islam secara langsung dapat dirasakan adalah ketika pembelajaran itu terjadi dan hal tersebut sangat berkatian dalam pemilihan materi ajar. Problem ini merupakan problem klasik dan belum ada solusi yang memuaskan hingga hari ini. Memang ruang lingkup materi Pendidikan Agama Islam sama dengan tujuh mata pelajaran karena materi Pendidikan Agama Islam merupakan ringkasan dari ilmu-ilmu yang selama ini seringkali disebut "ilmu-ilmu keislaman", yaitu al-Qur'an, hadits, akidah, aklak, fiqh, sejarah kebudayaan Islam, dan bahasa Arab. ${ }^{3}$

Sebenarnya bahasa Arab ini secara legal-formal tidak termasuk materi Pendidikan Agama Islam, namun guru Pendidikan Agama Islam apalagi siswa tidak mungkin mampu menguasai ajaran-ajaran Islam yang terdapat dalam al-Qur'an dan hadits Nabi tanpa penguasaan bahasa Arab sehingga bahasa Arab ini menjadi kewajiban tersendiri yang harus dikuasai oleh guru Pendidikan Agama Islam. Problem materi Pendidikan Agama Islam ini makin jelas ketika dibandingkan dengan alokasi waktu yang disediakan hanya dua jam pelajaran setiap minggu. Maka guru Pendidikan Agama Islam merasakan kesulitan mengajarkan materi Pendidikan Agama Islam yang begitu banyak sedangkan

\footnotetext{
${ }^{1}$ Pengantar Mujamil Qomar dalam buku karya Rahmat, Pendidikan Agama Islam Multidisipliner Telaah Teori dan Praktik Pengembangan PAI di Sekolah dan Perguruan Tinggi, (Yogyakarta: LKiS, 2017), hlm. vi. Baca juga, Baca Rahmat, Pendidikan Agama Islam Interdisipliner, Jogjakarta: Deepublish, 2016.

${ }^{2}$ Baca, Oemar Hamalik, Sistem Pembelajaran Jarak Jauh dan Pembinaan Ketenagaan, (Bandung: Trigenda Karya, 1994), hlm. 145.

${ }_{3}^{3}$ Muhaimin.Paradigma Pendidikan Islam Upaya Mengefektifkan Pendidikan Agama Islam Di Sekolah.(Bandung: Remaja Rosda Karya: 2001) hlm. 90.
} 
alokasi waktu yang disediakan hanya sedikit. Lantas apabila Bahasa Arab tidak dikuasai oleh guru atau dosen Pendidikan Agama Islam, lantas bagaiana dengan penguasaan Bahasa Inggris yang mana penguasaan bahasa ini dapat menambah khazanah ilmu sebab banyaknya literatur berbahasa tersebut serta bagaimana dengan disiplin ilmu lain yang memang sangat dibutuhkan dalam menganalisis setiap kajian dalam materi Pendidikan Agama Islam. Sebut saja disiplin psikologi. Ilmu Psikologi sangat berperan dalam perencanaan pembelajaran, implementasi bahkan sampai tahap penilaian siswa atau mahasiswa. ${ }^{4}$

Belum lagi dampak teknologi digital yang menuju revolusi era 4.0 dalam lima tahun kedepan akan mempengaruhi aktivitas kerja manusia karena semua telah dilayani dengan teknologi yang canggih. Dengan ketersediaan akses internet telah memudahkan masyarakat dalam setiap pemenuhan kebutuhannya sehari-hari, oleh karenanya setiap individu siswa atau mahasiswa perlu dibekali skill yang siap untuk memiliki competetive advantage (keunggulan persaingan) dengan pembekalan tidak hanya menguasai satu bidang disiplin ilmu ke-PAI-an melainkan juga disiplin ilmu lain seperti Sosiologi, Psikologi, Ilmu Politik dan lain sebagainya, serta tetap memiliki behavioral attitude (perilaku baik). ${ }^{5}$

\section{Metode}

Penelitian ini menggunakan pendekatan Kualitatif Deskriptif, yang dimulai pada pencarian pusat informasi dan mendeskripsikan, gambarpengumpulan data secara sistematis, penjelasan deskriptif bukan berbentuk angka. ${ }^{6}$ Sedangkan penelitian deskriptif yakni sebuah penelitian yang menjelaskan dan menggambarkan kejadian yang ada, baik kejadian alamiah maupun rekayasa manusia itu sendiri. ${ }^{7}$

Penelitian ini tefokus pada penelitian kepustakaan (Library Research), yakni sebuah penelitian yang terfokuskan pada pengumpulan data pustaka. ${ }^{8}$ Pengertian lain dari penelitian Livrary Research adalah sebuah penelitian yang menggunakan fasilitas kepustakaan seperti buku, koran, majalah, dokumen, dan catatan-catatan lainnya untuk mendapatkan informasi dan data. ${ }^{9}$

Penulis menggunakan penelitian ini berdasarkan pembahasan yang mengenai pendidikan era 4.0, dalam penelitian ini lebih terarah pada penggunaan model pendekatan isi kajian (Content Analysis), dimana sebuah pembahasan pengumpulan data secara mendalam melalui media cetak seperti buku, jurnal, ataupun media teknologi lainnya,

\footnotetext{
${ }^{4}$ Kamrani Buseri, dan Sembodo Ardi Widodo, "Seminar Nasional Pendidikan Agama Islam Era 4.0," pada tanggal 05 April, Website.pai.ikhac.ac.id, 2019.

${ }^{5}$ Hendra Suwardana, "Revolusi Industri 4 . 0 Berbasis Revolusi Mental," JATI UNIK 1, no. 2 (2017): 110.

6 Sudarwan Danim, Menjadi Peneliti Kualitatif : Rancangan Metodologi, Presentasi, Dan Publikasi Hasil Penelitian Untuk Mahasiswa Dan Peneliti Pemula Bidang Ilmu-Ilmu Sosial, Pendidikan, Dan Humaniora, 1 (satu) (Bandung: PT. Remaja Rosdakarya, 2002), 51.

${ }^{7}$ Lexy J. Moleong, Metodologi Penelitian Kualitatif(Bandung: PT. Remaja Rosdakarya, 2000), 3.

${ }^{8}$ Mahmud, Metode Penelitian Pendidikan (Bandung: Pustaka Setia, 2011), 31.

${ }^{9}$ Abdul Rahman Shaleh, Pendidikan Agama Islam Dan Pengembangan Untuk Bangsa (Jakarta: PT. Raja Grafindo Persada, 2005), 63.
}

Tribakti: Jurnal Pemikiran Keislaman

Volume 30, Nomor 2, Juli 2019 
yakni media ebook, dan tulisan-tulisan terdahulu sebagai sumber tambahan sebagai teori penulisan. ${ }^{10}$ Data tersebut dikumpulkan dengan cara Text Reading (membaca), memahami, mempelajari, dan mencatat sebuah informasi yang terkait permasalahan yang akan dikaji, sehingga mempermudah penyusunan penulisan.

\section{Pembahasan}

\section{Pendidikan Agama Islam Berwawasan Interdisipliner}

Keberadaan Pendidikan Agama Islam selayaknya tidak hanya membahas halal dan haram namun seyogyanya dapat mengambil peran penting dalam masalah-masalah sosial, seperti semakraknya isu-isu kemasyarakatan, yang berkaitan pengetahuan gender, lingkungan hidup, keberagaman dan dengan adanya beberapa isu-isu masyarakat sehingga membutuhkan solusi untuk menjawab berbagai problematika yang ada melalui ilmu pengetahuan sebagai jaringan ilmu yang saling berkaitan, oleh karenanya menjadi keniscayaan Pendidikan Agama Islam didekati dengan pendekatan Interdisipliner. ${ }^{11}$

Selama ini Pendidikan Agama Islam belum menggunakan pendekatan yang tepat. Akibatnya, menurut penilaian Mochtar Buchori maupun Soedjatmoko, kegiatan Pendidikan Agama Islam yang berlangsung selama ini cenderung bersikap menyendiri, kurang berinteraksi dengan kegiatan-kegiatan pendidikan lainnya. ${ }^{12}$ Pendidikan Agama Islam harus berinteraksi dan bersinkronisasi dengan pendidikan lainnya, jika menginginkan pembelajaran Pendidikan Agama Islam yang relevan dan responsif terhadap perkembangan zaman. Menurut penilaian saya, sebenarnya Pendidikan Agama Islam dengan mata pelajaran atau mata kuliah lainnya bisa dipadukan melalui pendekatan pembelajaran terpadu. Setidaknya, pelajaran maupun perkuliahan Pendidikan Agama Islam itu dapat didialogkan dengan pelajaraan maupun perkuliahan disiplin ilmu lainnya baik sejarah, sosiologi, ekonomi, geografi, kesenian, biologi, fisika, kimia, matematika, astronomi, kedokteran, farmasi dan sebagainya.

Seiring problem pendekatan ini pada tahap berikutnya juga timbul problem metode $^{13}$ dalam pembelajaran Pendidikan Agama Islam. Materi Pendidikan Agama Islam yang meliputi berbagai disiplin ilmu tersebut mencerminkan karakteristik yang kompleks sekali mulai dari materi yang bernuansa empirik, empirik-rasional, rasional, maupun suprarasional sehingga menuntut penggunaan metode yang bervariasi sesuai dengan karakteristik masing-masing materi Pendidikan Agama Islam tersebut. Sementara itu, selama ini mayoritas pendidik Pendidikan Agama Islam baik guru maupun dosen masih menggunakan metode konvensional tertentu yang monoton, sehingga penjelasanpenjelasan mereka tentang materi PAI itu kurang menyentuh substansinya dan kurang

${ }^{10}$ Abdurrahman Soejono, Metode Penelitian Suatu Pemikiran Dan Penerapan (Jakarta: Reneka Cipta, 1999), 25.

${ }^{11}$ Saifudin Mujtaba, "Studi Islam Interdisipliner : Sebuah Keniscayaan," At-Turas Jurnal Studi Keislaman II, no. 2 (2015): 170.

12 Khoiruddin Nasution, "Berpikir Rasional Ilmiah Dan Pendekatan Interdisipliner Dan Multidisipliner Dalam Studi Hukum Keluarga Islam,” Al-Ahwat 10, no. 1 (2017): 19.

${ }^{13}$ Kaelan, Metode Penelitian Agama Kualitatif Interdisipliner (Metode Penelitian Ilmu Agama Interdisipliner Dengan Ilmu Lain) (Yogyakarta: Paradigma, 2010), 20. 
menarik perhatian peserta didik. ${ }^{14}$ Akibatnya, pembelajaran Pendidikan Agama Islam kurang berhasil meskipun pada dataran kognitif (pengetahuan), apalagi pada dataran afektif (sikap dan perilaku) maupun psikomotorik (ketrampilan) tentu lebih memprihatinkan lagi. Untuk mengatasi problem-problem tersebut perlu ditemukan solusinya. Salah satu solusi ini adalah Pendidikan Agama Islam Interdisipliner.

\section{Pendidikan Agama Islam Era 4.0}

Pendidikan pada Era $4.0^{15}$ akan menjadi Pendidikan berbasis digital, dimana peranan Guru dalam pendidikan peserta didik sangat sedikit bahkan perannya dapat tergantikan oleh alat-alat digital pendidikan tersebut. Pendidikan Agama Islam di era 4.0 sebenarnya tidak dapat disamakan dengan pendidikan pada umumnya, sebab ilmu agama sudah semestinya diproleh dan diajarkan oleh para ulama sebagai warosatu al-Anbiya' (para ulama adalah pewaris para Nabi) ${ }^{16}$ Namun demikian, Pendidikan Agama Islam tidak kemudian alergi menggunakan teknologi ataupun alat digital dalam praktik pembelajaran atau perkuliah.

Dalam Pendidikan Agama Islam di era 4.0 $0^{17}$ sebuah lembaga (Perguruan Tinggi) dapat mengambil peluang dalam pelaksanaan pendidikan. Diantaranya dengan memadukan pembelajaran Pendidikan Agama Islam atau mata kuliah dengan disiplin ilmu umum, ${ }^{18}$ sehingga lulusan sarjana kelak tidak hanya memperoleh kajian ilmu Islam saja namun juga disiplin ilmu lainnya, maka tidak heran pendidik harus juga pandai dalam menerapkan sebuah sistem di lembaga sebagai solusi penambahan ilmu peserta didik untuk bekal pendidikan agama Islam era 4.0 itu.

Untuk menghadapi pendidikan Agama Islam kedepannya, terutama pada revolusi era 4.0 maka pendidikan Islam dianjurkan memiliki perombakan seperti yang dipaparkan di muka, khususnya pada pengarahan pendidikan agama Islam dengan pendekatan wawasan Interdisipliner, berikut ini tiga hal yang perlu dilakukan untuk Pendidikan Agama Islam di era 4.0 yakni :

\section{Disrupting Mindset}

Manusia berpikir sebelum melakukan tindakan. ${ }^{19}$ Hubungannya dengan pendidikan dengan pendidikan agama Islam adalah disaat zaman teknologi seperti sekarang menjadi acuan utama bagi masyarakat dalam memudahkan setiap kebutuhan yang memang selalu ingin serba cepat (instan), maka apabila Pendidikan Agama Islam tidak dapat merespon prilaku instan masyarakat tersebut akan dapat ditebak Pendidikan Agama Islam akan tenggelam dimakan zaman. Seperti kasus keinginan mahir membaca Al-Qur'an namun proses pembelajaran terkesan lama padahal kebutuhan untuk cepat membaca adalah sangat mendesak. Maka perlu memikirkan ulang upaya apa yang harus dilakukan sehingga bermunculan metode

\footnotetext{
${ }^{14}$ Muhaimin, Nuansa Baru Pendidikan Islam (Jakarta: PT. Raja Graffindo Persada., 2006), 102.

15 Sigit Priatmoko, "Memperkuat Eksistensi Pendidikan Islam Di Era 4.0," hlm. 10.

16 Baca, Zainul Muhibbin Pendidikan Islam membangun Karakter madani(LiteraJannata Perkasan 2012), hlm. 5

${ }^{17}$ Hendra Suwardana, Revolusi Industri 4. 0 Berbasis Revolusi Mental, JATI UNIK, Vol.1, No.2, (2017), Hal. 102-110/ TA" LIM : Jurnal Studi Pendidikan Islam Vol.1 No.2 Juli 2018

${ }^{18}$ Zainuddin, Paradikma Pendidikan Terpadu, (UIN Malang Press 2008) hlm. 3 .

${ }^{19}$ Rhenald Kasali, Disruption : "Tak Ada Yang Bisa Diubah Sebelum Dihadapi Motivasi Saja Tidak Cukup” (Jakarta: PT. Gramedia Pustaka Utama, 2017), 305.
}

Tribakti: Jurnal Pemikiran Keislaman

Volume 30, Nomor 2, Juli 2019 
atau materi ajar baca Al-Qur'an yang cepat dan mudah bahkan telah berbasis internet atau android. Dengan adanya serba kecepatan ini, maka mindset perlu diperhatikan dan dikembangkan pada pendidikan agama Islam.

Prinsip orang memiliki mindset baik, pertama yakni bekerja tidak harus terikat pada tempat dan waktu (tidak dibatasi jam dan ruangan kerja), sehingga beranggapan waktu dan tempat bukan penghalang lagi untuk melakukan sebuah pekerjaan karena tingginya mobilitas tersebut, maka lembaga pendidikan Islam bisa menerapkan management ini pada lembaganya, sehingga terbentuknya sistem yang efektif dan efisien, dan guru atau dosen akan lebih leluasa dalam menjalankan tugas dan fungsinya sebagai pendidik.

Kemudian yang kedua mengunggulkan pada Pelayanan proaktif, jadi seorang guru atau dosen dituntut kreatif dan inovatif dalam menggunakan alat-alat praga pembelajaran (media) di setiap pembelajaran atau pekan perkuliahan. ${ }^{20}$

Ketiga yakni memanfaatkan media sosial dengan baik, karena dengan adanya media sosial lebih mudah dalam mengakses sebuah informasi, jika demikian pendidikan Islam harus memaksimalkan media sosial ini sesuai dengan kebutuhan pendidikan agama Islam.

\section{Self Driving}

Jika dikaitkan dalam sebuah organisasi, maka self Driving dibutuhkan oleh seorang pemimpi. Begitupun jika dikaitkan dengan lembaga maka ini ditujukan pada pemimpin sebuah lembaga Islam, pemimpin yang berpijakan pada prinsip ini menunjukkan sikap yang lebih kritis, inovatif, tangkas, dan selalu update informasi. Mampu bekerja secara efektif dan efisien, serta cepat dalam bertindak, dan mampu memilah situasi yang baik dan buruknya baik sebuah lembaga tersebut, maka ini sangat dibutuhkan untuk lembaga pendidika agama Islam dengan memiliki pemimpin yang handal dalam mengemudi sebuah lembaganya (Perguruan Tinggi).

\section{Reshape or Create}

Dalam sebuah budaya Ahlus Sunnah Wal Jama'ah bahwa "Mempertahankan yang lama dalam hal yang baik, dan mengambil hal baru yang lebih baik”, jika dikaitkan dengan pendidikan Islam era 4.0 maka menjadi sebuah pilihan bagi pendidikan agama Islam pada zaman yang serba cepat ini, pilihan tersebut yakni reshape yang berati mempertahan sistem lama yang baik misalnya, namun di era 4.0 tidak cukup jika hanya mempertahankan, namun perlunya juga meodifikasi sistem yang lama sesuai dengan perkembangan zaman yang ada, misalnya pada managemen dan profesionalitas, seorang guru perlu adanya peningkatan pada kompetensinya, dimana kompetensi tersebut bisa didapatkan melalui seminar, loka karya, studi lanjut, dan diklat yang biasa dilakukan di Indonesia.

Kemudian plihan kedua yakni pada Create, yang pada prinsipnya mengambil hal baru yang lebih baik untuk diaplikasikan dalam lembaga atau Peruguran Tingginya, ${ }^{21}$ suatu misal merubah sistem pendidikan yang lama dengan sitem

\footnotetext{
${ }^{20}$ Sigit Priatmoko, TA" LIM : Jurnal Studi Pendidikan Islam .Vol.1 No.2 Juli 2018 .

${ }^{21}$ Baca, Syamsul Ma" arif, Revitalisasi Pendidikan Islam, (Yogyakarta: Graha Ilmu, 2007), hlm.
} $1-2$. 
pendidikan yang berbasis digital, alasanya sistem yang lama memungkinkan tidaklah menguntungkan bagi eksistensi lembaga atau perguruan tinggi, sehingga kemudian diberlakukan pembelajaran berbasis E-Learning, dimana sepenuhnya memaksimalkan dan memanfaatkan teknologi.

\section{Pendidikan Agama Islam Berwawasan Interdisipliner corak dan solusi Pendidikan Agama Islam Era 4.0}

\section{Pemilihan 5 (Lima) Disiplin Ilmu (Mata Kuliah)}

Pada era 4.0 yang dikenal serba Digital Melayani (DILAN), sepatutnya pendidikan Islam secara umum beserta komponen-komponen yang ada di dalamnya diperbaharui. Pendidikan Agama Islam yang sudah terbiasa dengan sistem pengajaran berparadigma teacher center agar beralih pada student center. Hal ini dilatar belakangi pada era 4.0 ini seluruh siswa maupun mahasiswa dalam belajar telah dapat mengakses dengan cepat informasi dari berbagai media termasuk media internet.

Dengan begitu, peran pendidik ialah mengarahkan serta membantu peserta didik dalam proses berjalannya pendidikan dan memantau dan memberikan arahan ketika proses pembelajaran peserta didik mengalami kesulitan belajar. Hal ini sesuai dengan Firman Allah Q.S an-Nahl : 43 yang berbunyi :

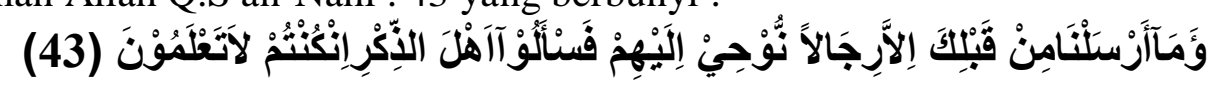

Terjemahnya: "Dan Kami tidak mengutus sebelum Engkau (Muhammad), melainkan orang laiki-laki yang kami beri wahyu kepada mereka : maka bertanyalah kepada orang yang mempunyai pengetahuan, jika kamu tidak mengetahui". ${ }^{22}$

Maka maksud dari ayat diatas adalah Etika seorang peserta didik atau mahasiswa dalam proses pendidikan ialah bertanya kepada yang lebih ahli (mempunyai ilmu). Maka jelas bahwa dalam revolusi industri 4.0 belum mampu menggeser posisi guru dalam pendidikan Islam walaupun dengan segala macam produk digital yang telah tercipta. Maka Pendidikan Islam saat ini dibutuhkan pendekatan interdisipliner yang relevan melalui inovasi implementasi pendidikan agama Islam, antara ilmu pengetahuan agama dan ilmu pengetahuan umum dan seperti wawasan global lainnya.

Jauh sebelum tulisan ini penulis buat, Kemenag telah memberikan solusi terhadap problem pendidikan guna menyambut era 4.0 ini. khususnya dalam Pendidikan Agama Islam dari perspektif pendekatan dan hal ini menghasilkan persetujuan pembukaan program studi baru terhadap beberapa program pascasarjana di Perguruan Tinggi Agama Islam baik negeri maupun swasta sebagai bentuk solusi yang sifatnya legal-formal-normatif. Seperti Kementerian Agama telah berupaya

${ }^{22}$ Al-Qur'an Surat an-Nahl : 43.

Tribakti: Jurnal Pemikiran Keislaman

Volume 30, Nomor 2, Juli 2019 
merintis solusi menghadapi era 4.0 dengan mengarahkan dan menetapkan pembukaan program studi PAI baru yang mencerahkan dan mendukung integrasi Islam dengan ilmu pengetahuan khususnya pada tingkat pascasarjana S-3, seperti PAI Multidisipliner di UIN Maulana Malik Ibrahim dan PAI Multikultural di Universitas Islam Malang. Solusi yang diprakarsai oleh Kemenag ini paling tidak berupaya menjawab salah satu problem PAI dari sudut pendekatan, yang mana PAI disinyalir oleh para kritikus sebagai kegiatan pembelajaran/perkuliahan yang cenderung mengisolasi tersebut.

Dalam hal ini maka penulis menawarkan inovasi Pendidikan Agama Islam Berwawasan Interdisipliner untuk corak dan solusi Pendidikan Agama Islam Era $4.0^{23}$ berupa 5 (Lima) disiplin keilmuah dan atau materi pembelajaran (Mata kuliah) yaitu Mata Kuliah Bahasa Arab, Bahasa Inggris, Informasi dan Teknologi (IT), Akuntansi, dan Mata Kuliah Ahlus Sunnah Wal Jama'ah (Aswaja). Sebenarnya 5 (Lima) mata kuliah yang penulis tawarkan tersebut merupakan representatif atau kelanjutan dari beberapa disiplin keilmuan yang pernah ditawarkan oleh Abuddin Nata dalam karyanya yang berjudul Ilmu Pendidikan Islam dengan Pendekatan Multidisipliner: normatif Perenialis, Sejarah, Filsafat, Psikologi, Sosiologi, Manajemen, Teknologi, Informasi, Kebudayaan, politik, dan Hukum dan atau yang pernah juga ditawarkan oleh Rahmat dalam karyanya yang berjudul Pendidikan Agama Islam Multidisipliner Telaah Teori dan Praktik Pengembangan Pai di Sekolah dan Perguruan Tinggi, Yogyakarta: LKiS, 2017 yang menekankan pada pendekatan Sains, Ekonomi, Sosiologi, Psikologi \& Tasawuf, dan pendekatan Politik.

Adapun ke-5 disiplin ilmu yang peneliti tawarkan sebagai wawasan interdisipliner Pendidikan Agama Islam era 4.0 yaitu 1) Disiplin Bahasa Arab, 2) Bahasa Inggris, 3) IT, 4) Akuntansi, dan 5) Aswaja, sebagaimana berikut:

Pertama, Disiplin ilmu Bahasa Arab. Bahasa Arab senyatanya bukan merupakan bahasa kalangan muslim saja serta bukan satu-satunya bahasa yang dimiliki agama Islam, namun bahasa Arab merupakan bahasa yang sangat penting dalam Islam dikarenakan hubungannya dengan keberadaan Nabi Muhammad SAW sebagai bangsa Arab dan sumber ajaran Islam itu sendiri yaitu Alquran yang ternyata disampaikan dalam bahasa Arab. ${ }^{24}$ Dan untuk memahami dan mengkaji isi dan kandungan Alquran dibutuhkan berbagai macam ilmu-ilmu yang berhubungan dengannya, seperti berbagai fan (disiplin) ilmu pula seperti tafsir, ushul fiqh, Sharaf, Nahwu, Balaghah, dan lain sebagainya, yang keseluruhan itu sangat bergantung dengan bahasa Arab.

Sehingga menjadi probelm sendiri apabila guru atau dosen Pendidikan Agama Islam kemudian tidak mampu secara professional berbincang dengan bahasa Arab. Tanpa penguasaan bahasa Arab sebagai bahasa yang digunakan oleh al-Qur'an

${ }^{23}$ Baca, Chanifudin, "Pendekatan Interdisipliner : Tata Kelola Pendidikan Islam di Tengah Kompleksitas.” Edukasi Islami Jurnal Pendidikan Islam 05 (2016): 1285.

${ }^{24}$ Bakalla, MH., Pengantar Penelitian Studi Bahasa Arab, Terj. dari Arabic Culture, Through Its Language and Literature oleh Males Sutiasumarga, (Jakarta: Hardjuna Dwitunggal, 1984), hlm. 1.

Tribakti: Jurnal Pemikiran Keislaman

Volume 30, Nomor 2, Juli 2019 
dan hadits, guru PAI tidak akan mampu menguasai materi PAI secara memadai karena bahasa Arab sebagai alat dalam memahami ajaran-ajaran Islam. Oleh karena itu, penguasaan bahasa Arab bagi guru PAI sebagai kewajiban mutlak yang tidak bisa dihindari maupun ditukar dengan penguasaan bidang-bidang keilmuan lain sebagai penggantinya. Sementara itu, penguasaan bahasa Arab ini menjadi poros kelemahan guru PAI di Indonesia.

Memang ruang lingkup materi PAI sama dengan tujuh mata pelajaran karena materi PAI merupakan ringkasan dari ilmu-ilmu yang selama ini seringkali disebut "ilmu-ilmu keislaman", yaitu al-Qur'an, hadits, akidah, aklak, fiqh, sejarah kebudayaan Islam, dan bahasa Arab. Sebenarnya bahasa Arab ini secara legal-formal tidak termasuk materi PAI, namun guru PAI apalagi siswa tidak mungkin mampu menguasai ajaran-ajaran Islam yang terdapat dalam al-Qur'an dan hadits Nabi tanpa penguasaan bahasa Arab $^{25}$ sehingga bahasa Arab ini menjadi kewajiban tersendiri yang harus dikuasai oleh guru PAI. Problem materi PAI ini makin jelas ketika dibandingkan dengan alokasi waktu yang disediakan hanya dua jam pelajaran setiap minggu. Maka guru PAI merasakan kesulitan mengajarkan materi PAI yang begitu banyak sedangkan alokasi waktu yang disediakan hanya sedikit.

Kedua, Disiplin ilmu Bahasa Inggris. Bahasa Inggris di dunia pendidikan, begitu juga pendidikan Islam memiliki peranan yang sangat urgen, dikarenakan dengan bahasa ini, menjadi kunci guna menguasai ilmu pengetahuan. Sebagai mahasiswa kita dapat membuka jendela ilmu pengetahuan dalam buku-buku berbahasa pengantar bahasa Inggris.

Sebagaimana yang kita ketahui, banyak rujukan pendidikan Islam memakai bahasa pengantarnya bahasa Arab, misal saja buku Ibnu Sina buku kedoktoran, Matematika oleh Al Jabar, politik serta sejarah oleh Ibnu Khaldun. Karya ulama kita tersebut kini dipelajari di dunia Barat baik di Jerman, Amerika, Canada, ataupun Inggris. Dan kitab-kitab tersebut telah diadopsi dan diadaptasi serta diterjemahkan dalam bahasa Inggris. ${ }^{26}$

Maka sepantasnya mahasiswa dan dosen Pendidikan Agama Islam mampu bercakap, membaca dan menulis menggunakan bahasa Inggris. Serta mempelajarai bahasa tersebut sebagai kebutuhan bukan sekedar kewajiban.

Kemudian yang ketiga, Disiplin ilmu IT (Ilmu Teknologi) Persepktif sosiologis, teknologi adalah satu dari banyak aspek yang ikut mempengaruhi tiaptiap sikap dan aktivitas,. Teknologi dapat mengubah hubungan dan interaksi antar manusia. Kehadirannya adalah suatu yang sangat erat kaitannya dengan manusia. Aktivitas manusia lambat laun akan dikuasai oleh keberadaan teknologi. Banyaknya teknologi modern ini dimulai dengan semakin canggihnya perangkat di bidang informasi serta komunikasi, satelit, bioteknologi, pertanian, peralatan di bidang kesehatan, dan rekayasa genetika. Kemunculannya mengilhami masyarakat digital

25 Baca, Mukram, Abd al-'Âl Sâlim, al-Lughah al-'Arabiyyah fi Rihâb al-Qur'an al-Karîm, (Kairo: 'Alam al-Kutub, 1995), hlm. 3.

${ }^{26}$ Baca, Alisjahbana, Sutan Takdir. The teaching of English in Indonesia. Dalam James Britton, Roberts E.Syeffer and Ken Watson (Eds.). Teaching and Learning English Worldwide. , 1990. hal: 315327.

Tribakti: Jurnal Pemikiran Keislaman

Volume 30, Nomor 2, Juli 2019 
dalam berbagai aspek kehidupan memberi bukti akan kemajuan teknologi. Masyrakat dan negara-negara dalam dunia saling berlomba untuk bisa menguasai puncak tertinggi dari teknologi (high tech) sebagai simbol kemajuan, kekuasaan, kekayaan dan prestise. Di kalangan masyarakat Postmodern diberlakukan hukum "Yang menguasai informasi dan teknologi maka akan menguasai dunia".

Dalam era 4.0, kemajuan dari teknologi berkembang dengan pesat sehingga sering sekali manusia sulit sekali mengikuti ritme kecepatan perkembangan dari teknologi tersebut. Akhirnya terjadi apa yang disebut anomi di tengah-tengah masyarakat karena tidak memiliki pegangan hidup yang jelas. Masyarakat menemukan kesulitan dalam penguasaan teknologi akan jatuh ke dalam cultural lag dan eksistensinya akan terancam. ${ }^{27}$ Adapun informasi yang teknologi yang dimaksud, minimal mahasiswa menguasai perangkat IT semisal hard ware dan soft ware komputer dan dapat setidaknya dapat mengoprasikan dengan sangat baik Microsoft Word, Exel dan Power Point dalam kehidupan sehari-hari..

Keempat, Disiplin Akuntansi. Akuntansi merupakan suatu kajian keilmuan yang berisikan rangkaian proses pemikiran yang menghasilkan suatu desain konseptual yang melingkupi prinsip, standar, metode, dan teknik, serta prosedur yang kemudian dijadikan pijakan ketika pelaporan keuangan serta informasi-informasi lainnya yang terkait guna melaporkan keadaan keuangan dari dalam sebuah kesatuan usaha. $^{28}$

Sehingga dengan kemampuan ilmu akuntansi yang baik, mahasiswa kelak akan dapat menjadi lulusan yang multitalent dalam segala bidang dalam hal mencatat dan menyajikan informasi atau lebih tepatnya lagi akuntansi merupakan satu sistem informasi dengan langkah-langkah mengidentifikasi, mencatat, serta mengkomunikasikan kejadian ekonomi dari satu organisasi kepada pihak-pihak yang memiliki kepentingan. Kemampuan akuntansi ini sangat diperlukan oleh mahasiswa khususnya ketika mereka para lulusan menjadi kepala sekolah atau manager sebuah lembaga pendidikan tertentu.

Kelima, Disiplin Aswaja. Ahlussunnah Wal Jama'ah adalah penggabungan dua suku kata yaitu ahl as-sunnah dan ahl al-jama'ah. ${ }^{29}$ Di dalam literatur bahasa Arab dalam kata $a h l$ berartikan "pengikut madzhab atau aliran", apabalila kata itu dihubungkan dengan madzhab (aliran). Adapun Al-Sunnah selain memiliki makna al-Hadits, berartikan juga "perilaku", prilaku baik ataupun prilaku yang tercela. Kata tersebut berasal dari sebuah kata sannan yang berartikan "jalan". 30

Berikutnya, berkenaan dengan pengertian al-Sunnah, merupakan suatu sikap mencontoh dan mengikuti Nabi SAW serta sahabat-sahabatnya, baik dalam hal ilmu, amal, akhlak, bahkan segala sendi kehidupannya. Maka, berlandaskan penjelasan ini, ahl al-Sunnah adalah mengikuti dan berpegang teguh kepada ajaran yang datangnya

27 Adib, Mohammad. Filsafat ilmu: onto-logi, epistemologi, aksiologi, dan logika ilmu pengetahuan. (Yogyakarta: Pustaka Pelajar, 2011), hlm. 254.

${ }^{28}$ Baca, Jurnal Ilmiah Mahasiswa Akuntansi, Vol. 1, No. 2, Maret 2012.

${ }^{29}$ Ahsin W. Alhafidz, Kamus Fiqih, Cet. 1, (Jakarta: Amzah, 2013), hlm. 9

${ }^{30}$ Munawir, Kajian Hadits Dua Mazhab, Cet. 1, (Purwokerto: Stain Press, 2013), hlm. 1. 
dari Rasulullah SAW (Al-Qur'an) dan yang dilanjutkan oleh para shahabat serta semua orang yang mengamalkan ajaran (Ijtihad) tersebut sampai hari kiamat itu tiba.

Sedangkan al-Jama'ah, asal kata al-jama'a dari tsulatsi mujarrad yajma'ujama'atan artinya "menyetujui”" atau "bersepakat". Oleh karena itu, al-jama'ah dapat juga diartikan teguh pendirian di jalan Allah SWT secara bersama-sama atau berjama"ah, jauh dari perselisihan dan perpecahan. ${ }^{31}$

Dan yang perlu dipertegas adalah meskipun kata al-jama'ah merupakan sebutan dari satu golongan yang bersatu, tetapi apabila al-jama'ah ini kemudian digabung dengan al-sunnah, yakni Ahl al-Sunah wa al-Jama'ah, maka yang diinginkan dengan kelompok ini mereka adalah, para pendahulu umat Islam yang pada barisan itu mereka sahabat-sahabat Nabi dan para tabi'in dalam satu persatuan menjalankan kebenaran yang datang dari dari Al-Qur'an dan Sunnah Nabi-Nya. ${ }^{32}$ Sehingga, ketika para mahasiswa lulus, mereka tidak hanya cakap berbahasa Arab dan Inggiris, mahir dalam bidang IT dan akuntansi, namun juga berakhlak selayaknya ahlu al-Sunnah wal Jama'ah.

\section{Kesimpulan}

Pendidikan Agama Islam dewasa ini belum dapat bersinergi dengan pendidikan umum dalam hal integrasi keilmuan bahkan terkesan dikotomi keilmuan, padahal baik ilmu agama maupun ilmu umum merupakan satu kesatuan dan keterpaduan. Hal ini apabila dibiarkan berlarut-larut akan menyebabkan Pendidikan Agama Islam tergeser dari perhatian dan minat masyarakat untuk dipelajari atau dipilih jurusan Pendidikan Agama Islam tersebut. Dan hal tersebut diperparah dengan keadaan implementasi pembeajaran Pendidikan Agama Islam yang terkesan tradisionalis konvensional dalam penerapan metode yang monoton (tidak kreatif) dan pengajaran materi ajar Pendidikan Agama Islam yang kurang sekali daya kreatifitas teknik pengajaran.

Belum lagi kemudian Pendidikan Agama Islam sekarang ini harus berhadapan dengan Era 4.0. Pada era 4.0 secara umum diartikan sebagai era pendidikan berbasis teknologi yang mengedapnkan kecepatan dalam memperoleh informasi. Dimana pendidikan pada era 4.0 penuh tuntutan untuk dapat bersaing dalam penyajian informasi bahkan pengajaran dan pelayanan pendidikan yang mudah dan cepat untuk diakses.

Dengan demikian, maka Pendidikan Agama Islam Berwawasan Interdisipliner dapat dijadikan sebagai corak dan solusi Pendidikan Agama Islam era 4.0. Karena keterbukaan atau keterpaduan disiplin Pendidikan Agama Islam dengan disiplin ilmu lainnya dirasakan akan dapat memberi dampak yang sangat baik dalam menghadapi era 4.0. Adapun disiplin-disiplin ilmu yang dimaksudkan sebagai wawasan interdisipliner di sini adalah 1) Disiplin ilmu Bahasa Arab, 2) Bahasa Inggris, 3) Informasi dan Teknologi (IT), 4) Akuntansi, serta 5) Aqidah Ahlu Al-Sunnah wa al-Jama'ah (Aswaja). Adapun ke5 disiplin ilmu ini dapat dijadikan sebagai mata kuliah wajib bagi mahasiswa setiap satu minggu sekali ataupun dapat dijadikan sebagai pegangan untuk dipelajari dan

\footnotetext{
${ }^{31}$ Baca, Nawawi, Ilmu Kalam: dari Teosentris Menuju Antroposentris, (Malang: Genius Media, 2014), hlm. 80-81

${ }^{32}$ Munawir, Kajian Hadits Dua Mazhab....... hlm. 56.
}

Tribakti: Jurnal Pemikiran Keislaman

Volume 30, Nomor 2, Juli 2019 
diaplikasikan oleh mahasiswa di luar mata kuliah wajib yang tersedia di perguruan tinggi maupun jurusannya.

Pada akhirnya, disiplin Bahasa akan menuntun lulusan sekolah maupun perguruan tinggi program studi Pendidikan Agama Islam lebih percaya diri dalam menghadapi era 4.0 yang mengedepankan komunikasi dan literasi berbahasa Arab dan Inggris. Disiplin IT dan Akuntansi akan dapat menginspirasi lulusan-lulusan tersebut dalam pengoprasian dan pengolahan informasi secara global sehingga dapat menyajikan nya dalam kualitas dan kuantitas yang baik dan cepat, serta disiplin Aswaja yang diharapkan dapat terus membentengi para lulusan agar tetap berpegang teguh dengan Al-Qur'an dan As-Sunnah yang diajarkan oleh para Sahabat dan Tabi'in serta para pengikutnya.

\section{Daftar Pustaka}

Adib, Mohammad. Filsafat ilmu: onto-logi, epistemologi, aksiologi, dan logika ilmu pengetahuan. Yogyakarta: Pustaka Pelajar, 2011

Ahsin W. Alhafidz, Kamus Fiqih, Cet. 1, (Jakarta: Amzah, 2013

Alisjahbana, Sutan Takdir. The teaching of English in Indonesia. Dalam James Britton, Roberts

Al-Qur'an Surat an-Nahl : 43.

Bakalla, MH., Pengantar Penelitian Studi Bahasa Arab, Terj. dari Arabic Culture, Through Its Language and Literature oleh Males Sutiasumarga, (Jakarta: Hardjuna Dwitunggal, 1984

Buseri, Kamrani dan Sembodo Ardi Widodo, "Seminar Nasional Pendidikan Agama Islam Era 4.0,” pada tanggal 05 April, Website.pai.ikhac.ac.id, 2019.

Chanifudin, "Pendekatan Interdisipliner: Tata Kelola Pendidikan Islam di Tengah Kompleksitas.” Edukasi Islami Jurnal Pendidikan Islam 05 (2016): 1285.

E.Syeffer and Ken Watson (Eds.). Teaching and Learning English Worldwide. , 1990

Jurnal Ilmiah Mahasiswa Akuntansi, Vol. 1, No. 2, Maret 2012

Kaelan, Metode Penelitian Agama Kualitatif Interdisipliner (Metode Penelitian Ilmu Agama Interdisipliner Dengan Ilmu Lain) Yogyakarta: Paradigma, 2010

Kasali, Rhenald, Disruption: "Tak Ada Yang Bisa Diubah Sebelum Dihadapi Motivasi Saja Tidak Cukup” Jakarta: PT. Gramedia Pustaka Utama, 2017.

Kasiram, M. Metode Penelitian Kualitatif dan kuantitatif Malang: UIN Press, 2008

Ma"arif, Syamsul, Revitalisasi Pendidikan Islam, Yogyakarta: Graha Ilmu, 2007 
Muhaimin, Nuansa Baru Pendidikan Islam Jakarta: PT. Raja Graffindo Persada., 2006

Muhaimin.Paradigma Pendidikan Islam Upaya Mengefektifkan Pendidikan Agama Islam Di Sekolah.Bandung: Remaja Rosda Karya: 2001

Mujtaba, Saifudin, "Studi Islam Interdisipliner : Sebuah Keniscayaan," At-Turas Jurnal Studi Keislaman II, no. 2 (2015)

Mukram, Abd al-'Âl Sâlim, al-Lughah al-'Arabiyyah fi Rihâb al-Qur'an al-Karîm, Kairo: 'Alam al-Kutub, 1995

Munawir, Kajian Hadits Dua Mazhab, Cet. 1, (Purwokerto: Stain Press, 2013

Nasution, Khoiruddin "Berpikir Rasional Ilmiah Dan Pendekatan Interdisipliner Dan Multidisipliner Dalam Studi Hukum Keluarga Islam,” Al-Ahwat 10, no. 1 (2017)

Nata, Abuddin, Ilmu Pendidikan Islam dengan Pendekatan Multidisipliner: normatif Perenialis, Sejarah, Filsafat, Psikologi, Sosiologi, Manajemen, Teknologi, Informasi, Kebudayaan, politik, dan Hukum, Jakarta: Rajawali Press, 2009

Nawawi, Ilmu Kalam: dari Teosentris Menuju Antroposentris, Malang: Genius Media, 2014

Oemar Hamalik, Sistem Pembelajaran Jarak Jauh dan Pembinaan Ketenagaan, (Bandung: Trigenda Karya, 1994

Priatmoko, Sigit, TA "LIM : Jurnal Studi Pendidikan Islam .Vol.1 No.2 Juli 2018 .

Rahmat, Pendidikan Agama Islam Interdisipliner, Jogjakarta: Deepublish, 2016.

------------, Pendidikan Agama Islam Multidisipliner Telaah Teori dan Praktik Pengembangan Pai di Sekolah dan Perguruan Tinggi, Yogyakarta: LKiS, 2017

Suwardana, Hendra, "Revolusi Industri 4 . 0 Berbasis Revolusi Mental," JATI UNIK 1, no. 2 (2017)

Suwardana, Hendra, Revolusi Industri 4. 0 Berbasis Revolusi Mental, JATI UNIK, Vol.1, No.2, (2017), Hal. 102-110/ TA"LIM : Jurnal Studi Pendidikan Islam Vol.1 No.2 Juli 2018

Zainuddin, Paradikma Pendidikan Terpadu, UIN Malang Press 2008

Zainul Muhibbin Pendidikan Islam membangun Karakter madani(LiteraJannata Perkasan 2012 